\title{
Scoping Study for the Adsorption of Tetraphenylborate Decompostion Products
}

by

K. B. Martin

Westinghouse Savannah River Company

Savannah River Site

Aiken, South Carolina 29808

T. L. White

C. W. Hsu

This paper was prepared in connection with work done under the above contract number with the U. S. Department of Energy. By acceptance of this paper, the publisher and/or recipient acknowledges the U. S.

Government's right to retain a nonexclusive, royalty-free license in and to any copyright covering this paper, along with the right to reproduce and to authorize others to reproduce all or part of the copyrighted paper. 


\section{DISCLAIMER}

This report was prepared as an account of work sponsored by an agency of the United States Government. Neither the United States Government nor any agency thereof, nor any of their employees, makes any warranty, express or implied, or assumes any legal liability or responsibility for the accuracy, completeness, or usefulness of any information, apparatus, product or process disclosed, or represents that its use would not infringe privately owned rights. Reference herein to any specific commercial product, process or service by trade name, trademark, manufacturer, or otherwise does not necessarily constitute or imply its endorsement, recommendation, or favoring by the United States Government or any agency thereof. The views and opinions of authors expressed herein do not necessarily state or reflect those of the United States Government or any agency thereof.

This report has been reproduced directly from the best available copy.

A vailable for sale to the public, in paper, from: U.S. Department of Commerce, National Technical Information Service, 5285 Port Royal Road, Springfield, VA 22161, phone: $(800)$ 553-6847, fax: (703) 605-6900 email: orders@ntis.fedworld.gov online ordering: http://www.ntis.gov/ordering.htm

Available electronically at http://www.doe.gov/bridge Available for a processing fee to U.S. Department of Energy and its contractors, in paper, from: U.S. Department of Energy, Office of Scientific and Technical Information, P.0. Box 62, Oak Ridge, TN 37831-0062, phone: (865)576-8401, fax: (865)576-5728 email: reportsbadonis.osti.gov 


\section{Scoping Study for the Adsorption of Tetraphenylborate Decomposition Products}

K. B. Martin

T. L. White

C. W. Hsu

January 06, 2000

Westinghouse

Savannah River Company

Aiken, SC 29808

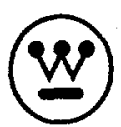

1

BNFL

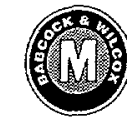




\section{DISCLAIMER}

Portions of this document may be illegible in electronic image products. Images are produced from the best available original document. 
WSRC-RP-99-01076

Page 1 of 6

Author,
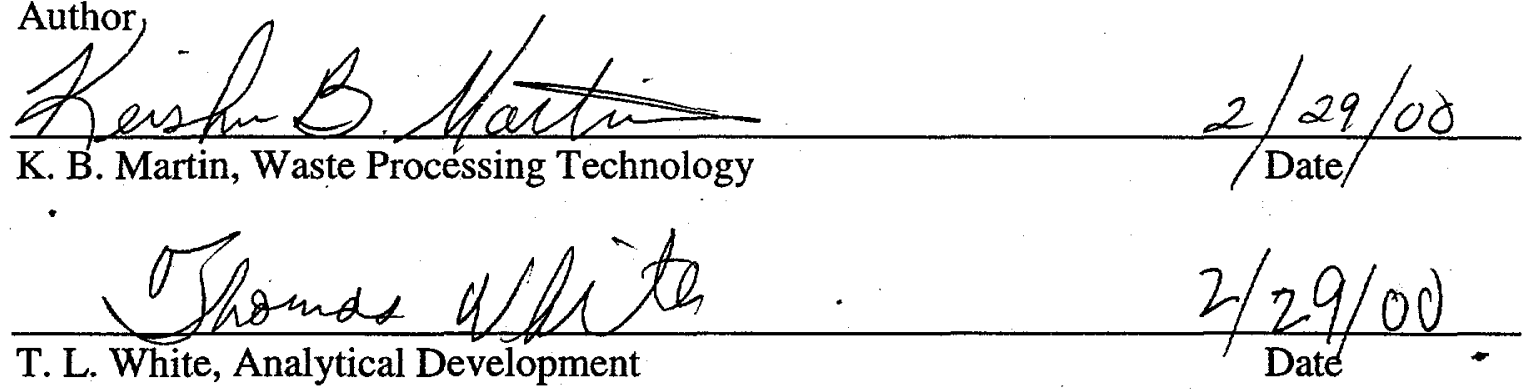

C.W. Her $2 / 29 / 00$

C. W. Hsu, Analytical Development

Date
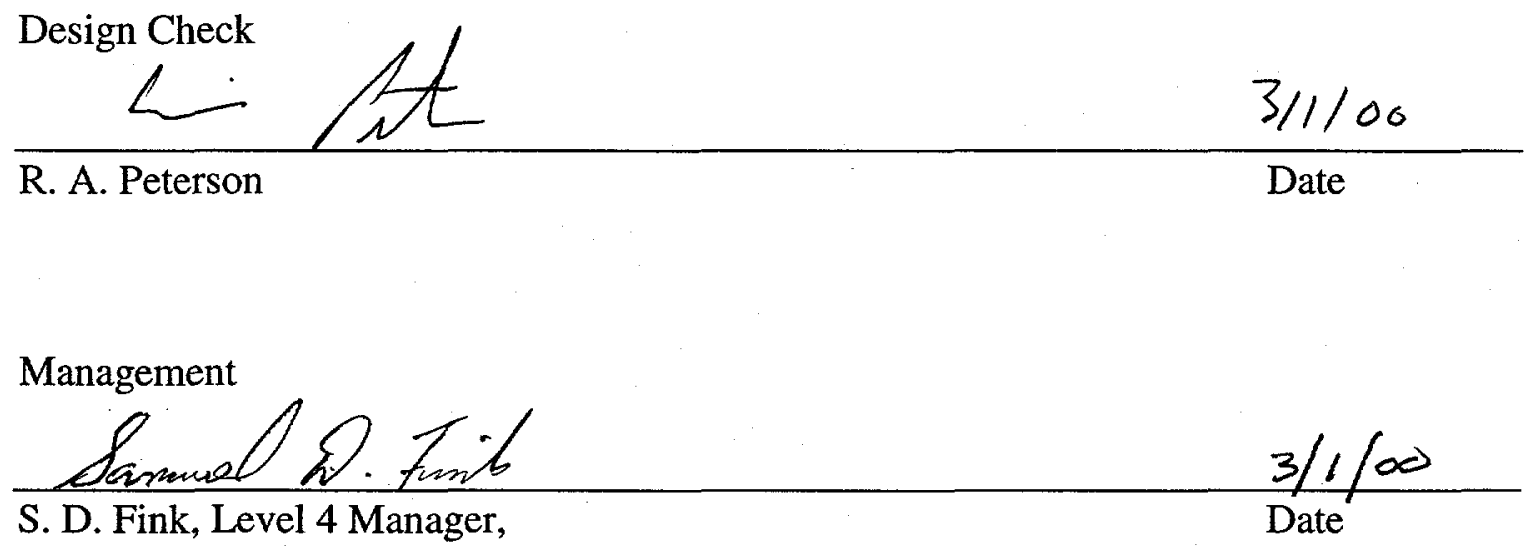

Waste Processing Technology

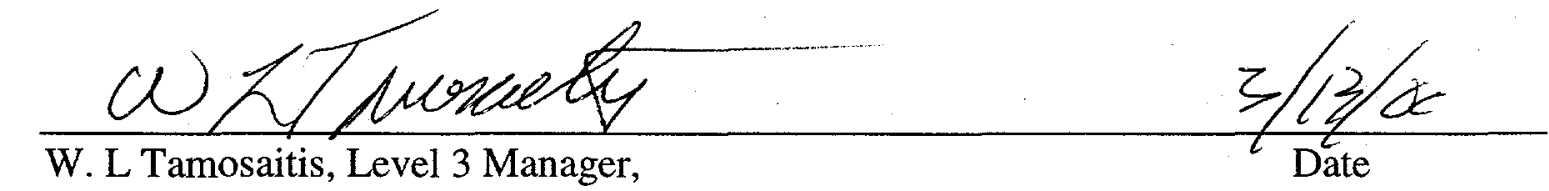
Waste Processing Technology

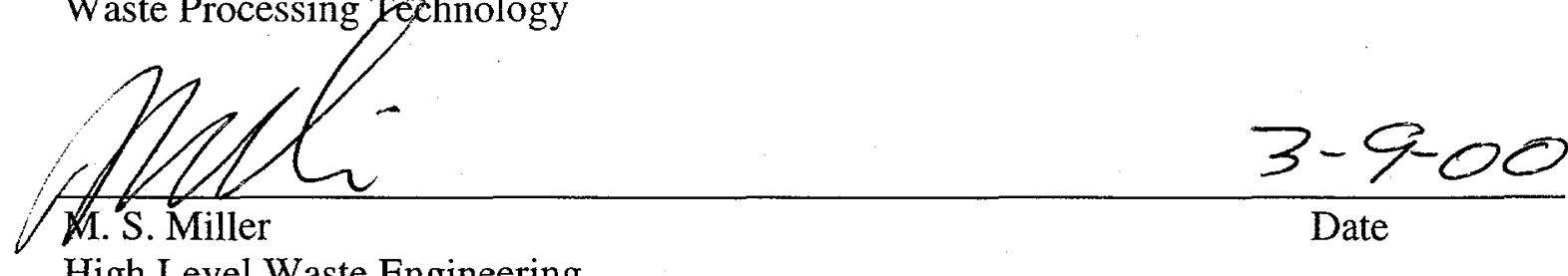

High Level Waste Engineering 


\section{Scoping Study for the Adsorption of Tetraphenylborate (TPB) Decomposition Products}

\section{SUMMARY}

This study examined the adsorption $\left(\mathrm{K}_{\mathrm{d}}\right)$ of tetraphenylborate decomposition products triphenylborane (3PB), diphenylborinic acid (2PB), and phenylboronic acid (1PB) from a simulated waste solution. The focus areas included three adsorbents: activated carbon, silica bonded with octyldecylsilane (C18), and silica bonded with a quaternary ammonium salt (Quat). The study examined the adsorbents at two concentrations, 100 and $200 \mathrm{~g} / \mathrm{L}$ in salt simulant. The following conclusions summarize the results:

- Activated Carbon exhibited significantly greater equilibrium coefficients for both diphenylborinic $\left(\mathrm{K}_{\mathrm{d}}=309 \mathrm{~mL} \mathrm{~g}\right)$ and phenylboronic $\left(\mathrm{K}_{\mathrm{d}}=4 \mathrm{~mL} / \mathrm{g}\right)$ acids in this application

- The low $\mathrm{K}_{\mathrm{d}}$ values indicate the need for an impractical quantity of adsorbent.

\section{INTRODUCTION}

Tank $49 \mathrm{H}$ currently contains approximately 83,000 gallons of the initial 180,000 gallons of wash water transferred in from the In-Tank Precipitation Process Demonstration conducted in 1983. Current analyses of waste samples indicate that the tank contains about $12 \mathrm{~g} / \mathrm{L}$ of the TPB decomposition intermediates (3PB, 2PB, \& $1 \mathrm{~PB}$ ) in the aqueous phase. ${ }^{1}$ Over time, these compounds generate flammable benzene as they decompose to mainly boric acid, phenol and benzene. Removal of these decomposition products would allow for safe disposal of the tank waste. High Level Waste Engineering would like to disposition the contents of Tank $49 \mathrm{H}$ to allow for additional tank space for the addition of new waste. ${ }^{2}$ This study evaluates three sorbents for the removal of the intermediates. The evaluation includes determination of the equilibrium distribution coefficient $\left(\mathrm{K}_{\mathrm{d}}\right)$ the mass of absorbed intermediates relative to the final concentration of intermediates in the salt solution -- as illustrated in the following formula.

$$
K_{d}=\left(\frac{\text { Concentration } \text { Initat }}{\text { Concentration }}-1\right) \times \frac{\text { Volume of Salt Solution }}{\text { Weight of Adsorbent }}
$$

\section{EXPERIMENTAL PROCEDURE}

Testing examined the feasibility of the three adsorbents as filtering agents listed in Table 1 on a $5.6 \mathrm{M} \mathrm{Na}^{+}$, average hydroxide composition simulated salt solution (Table 2, FFF$3,8 / 11 / 99$ ). Test 1 evaluated the effects of silica bonded octyldecylsilane (C18) and silica bonded with a quaternary ammonium salt (Quat). Test 2 evaluated activated carbon. We selected non-polar C18 and activated carbon because of their ability to retain low concentrations of the TPB decomposition products. We chose Quat. sorbent for its relatively high polarity and ionization properties that may help retain the intermediates. 
The Analytical Development Section analyzed the samples with High Performance Liquid Chromatography (HPLC).

Table 1: Adsorbents

\begin{tabular}{|l|l|l|}
\hline Adsorbents & Particle Size & Manufacturers \\
\hline Activated Carbon & $4-.12 \mathrm{mesh}$ & Darco \\
\hline Silica bonded octadecylsilane & $40 \mu \mathrm{m}$ & J. T. Baker \\
\hline Silica bonded quaternary ammonium salt & $40 \mu \mathrm{m}$ & J. T. Baker \\
\hline
\end{tabular}

Table 2: Composition of Simulated Waste used in the Experiment

$\begin{array}{cc}\text { Analytes } & \text { Concentration }(\mathrm{M}) \\ \mathrm{Na}^{+} & 5.6 \\ \mathrm{~K}^{+} & 0.015 \\ \mathrm{Cs}^{+} & 0.00014 \\ \mathrm{OH}^{-} & 1.91 \\ \mathrm{NO}_{3}{ }^{-} & 2.14 \\ \mathrm{NO}_{2}^{-} & 0.52 \\ \mathrm{AlO}_{2}{ }^{-} & 0.31 \\ \mathrm{CO}_{3}^{2-} & 0.16 \\ \mathrm{SO}_{4}{ }^{2-} & 0.15 \\ \mathrm{Cl}^{-} & 0.025 \\ \mathrm{~F}^{2-} & 0.032 \\ \mathrm{PO}_{4}{ }^{3-} & 0.010 \\ \mathrm{C}_{2} \mathrm{O}_{4}{ }^{2-} & 0.008 \\ \mathrm{SiO}_{3}{ }^{2-} & 0.004 \\ \mathrm{MoO}_{4}{ }^{2-} & 0.0002\end{array}$

Test 1

Lab personnel prepared simulated average salt solution containing $53 \mathrm{mg} / \mathrm{L} 3 \mathrm{~PB}, 6525$ $\mathrm{mg} / \mathrm{L} 2 \mathrm{~PB}$, and $8021 \mathrm{mg} / \mathrm{L} 1 \mathrm{~PB}$. These concentrations fall well below the solubility limit for the compounds in the alkaline solution and researchers did not observe any second organic phase. Personnel weighed 1.0 gram and 2.0 grams of C18 and Quat each into four $30-\mathrm{mL}$ polypropylene bottles. They then added $10-\mathrm{mL}$ of the salt solution to each bottle. Personnel capped and taped the bottles, and placed them in a horizontal Cole/Parmer Polystate water bath shaker (controlled at $25^{\circ} \mathrm{C}$ and $120 \mathrm{rpm}$ ) for 24 hours.

\section{Test 2}

Lab personnel prepared simulated average salt solution containing $1018.1 \mathrm{mg} / \mathrm{L} 3 \mathrm{~PB}$, $4997.7 \mathrm{mg} / \mathrm{L} 2 \mathrm{~PB}$, and $8026 \mathrm{mg} / \mathrm{L}$ 1PB. These concentrations fall well below the solubility limit for the compounds in the alkaline solution and researchers did not observe any second organic phase. Personnel weighed 1.0 gram and 2.0 grams of activated carbon (Size 4-12 mesh) into two polypropylene bottles and added 10-mL of salt 
solution. Personnel capped and taped the bottles, and placed them in a horizontal Cole/Parmer Polystate water bath shaker (controlled at $25^{\circ} \mathrm{C}$ and $120 \mathrm{rpm}$ ) for 24 hours.

\section{Analyses}

In both test sets, personnel analyzed the change in concentration $(\mathrm{mg} / \mathrm{L})$ for $3 \mathrm{~PB}, 2 \mathrm{~PB}$, and 1PB using HPLC. Based on initial sample results, the author calculated $\mathrm{K}_{\mathrm{d}}$ for samples taken at 1.5 and 24 hours. Sample analyses at 1.5 hours helped to determine if rapid equilibrium occurred. Generally, equilibrium occurred between analytes and sorbents within 24 hours.

\section{RESULTS \& DISCUSSION}

Personnel collected samples at 1.5 hours and 24 hours from both test sets. Table 3 provides the $\mathrm{K}_{\mathrm{d}}$ values determined in Test 1 . Both adsorbents removed 3PB to levels below the detection limit of the HPLC. Thus, the $K_{d}$ value for $3 P B$ uses the concentration at the detection limit $(10 \mathrm{mg} / \mathrm{L})$ as the final concentration. However the quantities tested did not adsorb high levels of the 2PB and 1PB. The C18 and the Quat sorbent appeared to reach equilibrium within 1.5 hours since little change occurred in $K_{d}$ values at 1.5 and 24 hours for $2 \mathrm{~PB}$ and 1PB. The amount of sorbent used had little effect on the $\mathrm{K}_{\mathrm{d}}$ values obtained for $\mathrm{C} 18$ and Quat. No increase in the phenol concentration occurred during the 24 hour run indicating adsorption rather than decomposition of the analytes.

Table 3: $K_{d}$ Values for Test 1

\begin{tabular}{|l|c|c|c|}
\hline $\mathbf{1 . 5}$ Hour Sample & & & \\
\hline Sample ID & 3PB (mL/g) & 2PB (mL/g) & $1 \mathrm{~PB}(\mathrm{~mL} / \mathrm{g})$ \\
\hline $1.0 \mathrm{~g} \mathrm{C18}$ & 22 & 7 & 1 \\
\hline $1.0 \mathrm{~g}$ Quat & 22 & 1 & 0 \\
\hline $2.0 \mathrm{~g}$ C18 & 11 & 15 & 4 \\
\hline $2.0 \mathrm{~g}$ Quat & 11 & 1 & 0 \\
\hline 24 Hour Sample & & & 2 \\
\hline $1.0 \mathrm{~g}$ C18 & 22 & 6 & 2 \\
\hline $1.0 \mathrm{~g}$ Quat & 22 & 4 & 2 \\
\hline $2.0 \mathrm{~g}$ C18 & 11 & 6 & 2 \\
\hline $2.0 \mathrm{~g}$ Quat & 11 & 6 & \\
\hline
\end{tabular}


Table 4 provides the $K_{d}$ values determined from Test 2 . The activated carbon adsorbed 3PB to levels below the detection limit of the HPLC; therefore the $K_{d}$ value uses the detection limit as the final concentration. For the 24-hour samples, an increase of less than $10 \mathrm{mg} / \mathrm{L}$ to approximately $500 \mathrm{mg} / \mathrm{L}$ in phenol concentration accompanied the reduction of concentration of $3 \mathrm{~PB}$. A control sample showed no increases in phenol, suggesting that the activated carbon plays a role in the decomposition of $3 \mathrm{~PB}$. The activated carbon may to a lesser extent play a role in the decomposition of $2 \mathrm{~PB}$ and $1 \mathrm{~PB}$. The calculated $2 \mathrm{~PB}$ distribution value increased significantly between 1.5 and 24 hours. The 1PB analyte showed little affinity for the sorbent. The $K_{d}$ values for activated carbon proved higher than the $\mathrm{K}_{d}$ values for both the $\mathrm{C} 18$ and Quat adsorbents.

Table 4: $K_{d}$ Values for Test 2

\begin{tabular}{|l|r|c|c|}
\hline 1.5 Hour Sample & & & \\
\hline Sample ID & $3 \mathrm{~PB}(\mathrm{~mL} / \mathrm{g})$ & $2 \mathrm{~PB}(\mathrm{~mL} / \mathrm{g})$ & $1 \mathrm{~PB}(\mathrm{~mL} / \mathrm{g})$ \\
\hline $1.0 \mathrm{~g}$ Carbon & 1129 & 13 & 3 \\
\hline $2.0 \mathrm{~g}$ Carbon & 565 & 12 & 2 \\
\hline 24 Hour Sample & & & \\
\hline $1.0 \mathrm{~g}$ Carbon & 1130 & 166 & 3 \\
\hline $2.0 \mathrm{~g}$ Carbon & 565 & 309 & 4 \\
\hline
\end{tabular}

Operations must remove a sufficient amount of the intermediates to minimize benzene formation potential in an air-based mode, and for transfer to Tank $50 \mathrm{H}$. The acceptance limits for transfer to Tank $50 \mathrm{H}$ for benzene and sodium tetraphenlyborate are $3 \mathrm{mg} / \mathrm{L}$ and $1000 \mathrm{mg} / \mathrm{L} .^{3}$ The rate of benzene generation from TPB and its decomposition products shall remain less than $0.02 \mathrm{mg} / \mathrm{L} / \mathrm{h}$ at $40^{\circ} \mathrm{C} .^{3}$ Assumed acceptable concentrations of $2 \mathrm{~PB}$ and $1 \mathrm{~PB}$ are $650 \mathrm{mg} / \mathrm{L}$ and $350 \mathrm{mg} / \mathrm{L}$. To reduce $1 \mathrm{~PB}$ to its acceptable limit would require approximately 1.8 million $\mathrm{KG}$ of activated carbon (See Appendix I).

At a cost of $\$ 2 / 1 \mathrm{~b}$, the estimated carbon price for this process is $\$ 7,936,641.44$. The Effluent Treatment Facility (ETF) utilizes $10,000 \mathrm{KG}$ of carbon which requires an ASME section VIII code stamped process vessel rated for $150 \mathrm{psi}$ with the following dimensions; $10 \mathrm{ft}$. in diameter and $10 \mathrm{ft}$ deep. ${ }^{4}$ This process would utilize 180 charges for such a vessel for the amount of carbon required to process the waste. Implementation would also require further studies to investigate waste disposal cost, which varies widely depending on the waste form (e.g., hazardous, mixed, LLW, and TRU). 


\section{CONCLUSION}

The activated carbon adsorbed the intermediates at a higher level than the C18 and Quat. Adsorption is a viable process, however the low $\mathrm{K}_{d}$ values indicate the need for an impractical amount of adsorbent to get to the desired decontamination factors.

\section{REFERENCES}

${ }^{1}$ K. B. Martin, T. B. Peters, "Combined R\&D Program for Tank 49H (JCO and Content Disposition)", WSRC-RP-99-01069, November 21, 1999.

${ }^{2}$ R. C. Fowler, "The Waste Stored in Tank 49", WPT-TAR-99001, January 3, 2000.

${ }^{3}$ WSRC 1S Savannah River Site Waste Acceptance Criteria Manual, "Procedure 4.01 Acceptance Criteria for Aqueous Waste Sent to the Z Area Saltstone Production Facility", Rev. 2, June 19, 1998.

${ }^{4}$ Wiggins, Arthur, CC Mail Correspondence dated 1/27/000, “Re[2]: Carbon Bed Usage at ETF". 


\section{APPENDIX I}

\section{Input}

1. $\mathrm{K}_{\mathrm{d}}=4 \mathrm{~mL} / \mathrm{g}=4 \mathrm{~L} / \mathrm{kg}$ for $1 \mathrm{~PB}, 2.0$ grams of activated carbon

2. Initial $1 \mathrm{~PB}$ concentration in the waste simulant equals $8026 \mathrm{mg} / \mathrm{L}$.

Note: Removal of 1PB represents the limiting organic given the results of the adsorption study given in Table 4 (i.e., lowest distribution coefficient for activated carbon existed for 1PB)

\section{Assumptions}

1. Final $1 \mathrm{~PB}$ concentration should $\leq 350 \mathrm{mg} / \mathrm{L}$ based on limits to transfer waste to Tank $50 \mathrm{H}$.

2. Assume 83,000 gallons of waste are in Tank $49 \mathrm{H}$.

\section{Calculation}

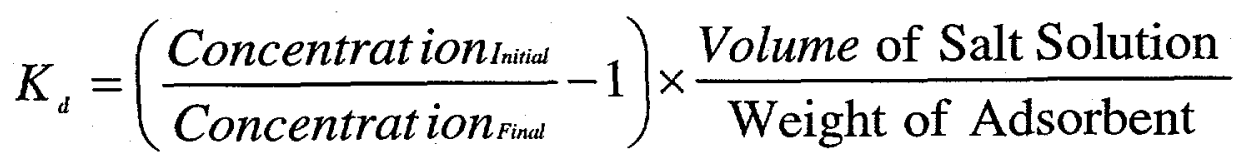

Weight of Adsorbent $=\left[\left(\frac{8026}{350}-1\right) * \frac{314,189.2 \text { Liters }}{4 \mathrm{~L} / \mathrm{kg}}\right]$

Weight of Adsorbent $=1,722,654 \mathrm{~kg} \approx 1.8 \mathrm{M} \mathrm{kg}$ 


\section{DISTRIBUTION:}

D. A. Barber, 703-H

M: J. Barnes, 773-A

R. J. Bentley, 241-119H

J. T. Carter, 704-3N

V. H. Dukes, 773-A

S. D. Fink, 773-A

F. F. Fondeur, 773-A

C. R. Geter, $241-152 \mathrm{H}$

D. T. Hobbs, 773-A

E. W. Holtzscheiter, 773-A

P. R. Jackson, 703-46A

R. T. Jones, 704-3N

B. L. Lewis, 703-H

T. J. Lex, 703-H

P. E. Lowe, 773-41A

K. B. Martin, 773-24A

J. W. McCullough, 704-3N

M. S. Miller, 704-56H

J. P. Morin, 703-H

L. M. Nelson, $773-43 \mathrm{~A}$

L. N. Oji, 773-43A

T. L. Ortner, 704-56H

L. M. Papouchado, 773-A

T. B. Peters, 773-24A

R. A. Peterson, 773-A

S. F. Piccolo, 704-3N

J. A. Pike, 704-3N

K. J. Rueter, 704-3N

P. L. Rutland, 704-196N

W. L. Tamosaitis, 773-A

W. B. Van Pelt, 773-42A

D. D. Walker, 773-A

W. R. Wilmarth, 773-42A

G. T. Wright, 773-A

STI, 703-43A

LWP Files c/o C. Canada, 773-A

ITP Files c/o C. Smalls, 241-147H 